\title{
PENGARUH KOMPETENSI PEDAGOGIK DOSEN TERHADAP MOTIVASI BELAJAR MAHASISWA PENDIDIKAN IPS
}

\author{
Akhmad Munaya Rahman, Mutiani , M. Adhitya Hidayat Putra \\ FKIP Universitas Lambung Mangkurat Banjarmasin \\ Email: mutiani@ulm.ac.id
}

\begin{abstract}
The purpose of this study was to determine the effect of lecturer pedagogic competence on learning motivation of Social Studies Department FKIP ULM students. The research method is used a quantitative approach. The research subjects consisted of 150 social studies students with full sampling. The data collection methods in the form of observation, literature study, documentation, and questionnaires. The data analysis was done by percentage techniques and simple linear regression analysis with the help of SPSS 16 for windows. The results showed that the pedagogic competence of lecturers was in the good category at $82.4 \%$, the learning motivation of students was in the sufficient category of $74.5 \%$. The results of simple linear regression analysis show that $t_{\text {count }}$ (5.712) $>t_{\text {table }}$ (1.976), it can be stated that the hypothesis test Ho is rejected and Ha is accepted. This study can be concluded that the pedagogical competence of lecturers has a significant influence on student learning motivation.
\end{abstract}

Keywords: Pedagogic Competence, Learning Motivation, Students in Social Science Education

\begin{abstract}
Abstrak
Tujuan penelitian ini untuk mengetahui pengaruh kompetensi pedagogik dosen terhadap motivasi belajar mahasiswa Pendidikan IPS FKIP ULM. Metode penelitian menggunakan pendekatan kuantitatif.Subjek penelitian berjumlah 150 mahasiswa pendidikan IPS dengan pengambilan sampel penuh.Metode pengumpulan data berupa observasi, studi pustaka, dokumentasi, dan angket.Analisis data dilakukan dengan teknik persentase dan analisis regresi linear sederhana dengan bantuan SPSS 16 for windows. Hasil penelitian menunjukkan bahwa kompetensi pedagogik dosen berada pada kategori baik sebesar 82,4\%, motivasi belajar mahasiswa berada pada kategori cukup sebesar $74,5 \%$. Hasil analisis regresi linear sederhana menunjukkan nilai $t_{\text {hitung }}(5,712)>$ $t_{\text {tabel }}(1,976)$, maka dapat dinyatakan bahwa uji hipotesisnya Ho ditolak dan Ha diterima.Penelitian ini dapat disimpulkan bahwa kompetensi pedagogik dosen berpengaruh secara signifikan terhadap motivasi belajar mahasiswa.
\end{abstract}

\section{Kata Kunci: Kompetensi Pedagogik, Motivasi Belajar, Mahasiswa Pendidikan IPS}




\section{A. Pendahuluan}

Keberhasilan pembelajaran ditentukan dari berbagai komponen yang saling berinteraksi. Komponen pembelajaran, di antaranya dosen, mahasiswa tujuan, materi, metode, dan strategi pembelajaran. Sebagaimana menurut Makmun (2007), mengemukakan ada tiga komponen yang penting dalam pembelajaran, yaitu (1) mahasiswa meningkatkan kemampuan akademik seoptimal mungkin melalui pembelajaran, (2) pengajar (dosen/guru) selalu menciptakan situasi yang tepat untuk belajar, sehingga memungkinkan untuk terjadinya pembelajaran, dan (3) tujuan, yaitu sesuatu yang diharapkan setelah pembelajaran. Komponenkomponen tersebut satu sama lain harus saling menunjang agar pembelajaran menjadi efektif dan efisien.

Profesi sebagai dosen sangat strategis dalam pembentukan dan pemberdayaan mahasiswa. Dosen memiliki peran dan fungsi yang semakin signifikan di masa mendatang. Melalui pendidikan, mahasiswa dibentuk menjadi manusia baru yang menyadari posisi dirinya dalam kehidupan bermasyarakat. Dengan demikian, pendidikan membentuk mahasiswa menjadi berwatak; beretika, dan berestetika melalui proses yang bukan hanya transfer of knowledgeakan tetapi juga proses transfer of values (Mustamin, 2013).

Undang-undang Nomor 14 Tahun 2005 tentang guru dan dosen menegaskan bahwa dosen sebagai agen pembelajaran berfungsi meningkatkan mutu pendidikan nasional. Fungsi tersebut agar terlaksana dengan baik, dosen wajib memiliki syarat di antaranya kompetensi. Ditegaskan melalui Peraturan Pemerintah RI Nomor 19 Tahun 2005 tentang Standar Nasional Pendidikan, menyatakan bahwa; pendidik harus memiliki kualifikasi akademik dan kompetensiguru dan dosen, sehat jasmani dan rohani, serta memiliki kemampuan untuk mewujudkan pendidikan nasional. Kualifikasi akademik merupakan tingkat pendidikan minimal seorang pendidik yang harus dipenuhi dan dibuktikan dengan ijazah atau sertifikat keahlian sesuai ketentuan perundang-undangan. Kompetensi dosen pada jenjang pendidikan tinggi menurut Undang-undang Nomor 14 tahun 2005 tentang Guru dan Dosen pasal 10 kompetensi yang dimiliki dosen meliputi: "kompetensi pedagogik, kepribadian, profesional, dan sosial". 
Satu di antara empat kompetensi seorang dosen, kompetensi pedagogik harus dikembangkan dari waktu ke waktu. Kompetensi pedagogik merupakan kemampuan dosen dalam merencanakan, melaksanakan, mengevaluasi, dan menindak lanjuti hasil pembelajaran agar menjadi lebih baik. Sebagaimana sesuai dengan Pasal 28 ayat 3 tentang standar nasional pendidikan dijelaskan bahwa kemampuan mengelola pembelajaran mahasiswa, perancangan, pembelajaran, evaluasi hasil belajar, dan pengembangan kompetensi mahasiswa. Upaya tersebut sangat penting dan strategis dalam menghadapi era persaingan yang semakin ketat. Perguruan tinggi harus mampu menghasilkan lulusan yang berkualitas dan berdaya saing sesuai dengan standar nasional dan standar internasional pendidikan. Lulusan harus menguasai hard skills dan soft skill sehingga dapat bersaing mencari lapangan pekerjaan pada tingkat lokal, nasional, dan global. Peningkatan pelaksanaan pembelajarandiharapkan agar kualitas lulusan semakin baik sehingga masa tunggu kerja lulusan semakin singkat. Dengan demikian, kemampuan seorang dosen dalam merencanakan, melaksanakan, dan mengevaluasi pembelajaran harus dikuasai.

Dosen berupaya merancang dan melaksanakan pembelajaran dengan baik, namun permasalahan akan tetap dijumpai. Pembelajaran akan terus berjalan secara dinamis sehingga dosen perlu mencermati perubahan yang terjadi pada mahasiswa. Dosen selalu berupaya agar bahan pelajaran yang disampaikan dapat dikuasai oleh mahasiswa secara tuntas. Permasalahan tersebut yang cukup sulit dirasakan oleh dosen. Kesulitan itu dikarenakan mahasiswa bukan hanya sebagai individu, tetapi juga sebagai makhluk sosial dengan latar belakang yang berbeda. Jadi, kompetensi yang paling diperlukan oleh seorang dosen agar dapat mengatasi permasalahan dalam pembelajaran agar mendapatkan hasil belajar yang baik adalah kompetensi pedagogik.

Undang-undang Nomor 14 Tahun 2005 tentang Guru dan Dosen bahwa kompetensi pedagogik adalah "kemampuan mengelola pembelajaran mahasiswa". Kompetensi pedagogik merupakan jenis kompetensi yang perlu dikuasai dosen. Kemampuan tersebut terlihat dari pengelolaan pembelajaran meliputi; pemahaman karakteristik mahasiswa, perencanaan dan pelaksanaan, evaluasi, dan pengembangan berbagai potensi mahasiswa. Pencapaian tujuan belajar diukur atau 
ditentukan dari hasil belajar. Berhasil tidaknya seorang mahasiswa dalam pembelajaran dapat terlihat dari hasil belajar atau yang sering kita kenal dengan prestasi belajar.

Fenomena di lapangan ada permasalahan mendasar yang dihadapi mahasiswa diantaranya diskusi yang kurang mengasah kemampuan, kurang aktifnya dalam mengikuti perkuliahan, dan kurang aktif Tanya jawab dengan dosen. Fenomena lain, kemampuan dosen dalam merencanakan dan melaksanakan pembelajaran masih kurang efektif. Saat pembelajaran dosen masih kurang variatif dalam penggunaan metode pembelajaran, bahan ajar yang kurang, dan media pembelajaran yang kurang dimanfaatkan. Kedua fenomena tersebut tentu sangat mempengaruhi akan keberhasilan seorang mahasiswa dan dosen dalam mencapai tujuan pembelajaran. Dengan demikian, perlu diteliti; (1) tingkat kompetensi pedagogik dosen, (2) tingkat motivasi belajar mahasiswa, dan (3) pengaruh kompetensi pedagogik dosen terhadap motivasi belajar mahasiswa Pendidikan IPS.

\section{B. Landasan Teori}

\section{Kompetensi Dosen}

Kompetensi merupakan perpaduan dari pengetahuan, ketrampilan, nilai dan sikap yang direfleksikan dalam kebiasaan berpikir dan bertindak. Mc Ashan (1981, dalam Mulyasa, 2003:79) mengemukakan bahwa kompetensi adalah pengetahuan, ketrampilan, dan kemampuan yang dikuasai oleh seseorang yang telah menjadi bagian dari dirinya sehingga ia dapat melakukan perilaku-perilaku kognitif, afektif, dan psikomotorik dengan sebaik-baiknya. Senada dengan hal tersebut lebih lanjut Finch dan Crunkilton (1979, dalam Mulyasa 2003:81) mengartikan kompetensi sebagai penguasaan terhadap suatu tugas, ketrampilan, sikap, dan apresiasi yang diperlukan untuk menunjang keberhasilan. Kompetensi dosen dalam pasal 10 Undang-undang Republik Indonesia Nomor 14 Tahun 2005, yaitu kompetensi pedagogik, kepribadian, sosial, dan profesional.

\section{Kompetensi Pedagogik}

Kemampuan dosen dalam mengelola pembelajaran, meliputi; a) pemahaman landasan kependidikan, b) pemahaman terhadap mahasiswa, c) 
pengembangan kurikulum/silabus, d) perancangan pembelajaran, e) pembelajaran yang mendidik dan dialogis, f) pemanfaatan teknologi pembelajaran, g) evaluasi pembelajaran dan hasil belajar, h) pengembangan mahasiswa untuk mengembangkan potensi yang dimilikinya.

\section{Indikator Kompetensi Pedagogik}

Penelitian ini, mengemukakan teori mengenai kompetensi pedagogik dosen, di bawah ini dicantumkan indikator kompetensi pedagogik dosen yang akan diteliti. Tabel 1 Indikator kompetensi pedagogik dosen, sebagai berikut.

Tabel 1 Indikator Kompetensi Pedagogik Dosen

\begin{tabular}{|c|c|c|}
\hline Variabel & Sub Variabel & Indikator \\
\hline $\begin{array}{l}\text { Kompetensi } \\
\text { Dosen }\end{array}$ & $\begin{array}{c}\text { Kompetensi } \\
\text { Pedagogik }\end{array}$ & $\begin{array}{l}\text { 1. Menguasai karakteristik peserta } \\
\text { didik } \\
\text { 2. Menguasai teori belajar dan prinsip- } \\
\text { prinsip pembelajaran } \\
\text { 3. Pengembangan kurikulum } \\
\text { 4. Pembelajaran yang mendidik } \\
\text { 5. Pengembangan potensi peserta didik } \\
\text { 6. Komunikasi dengan peserta didik } \\
\text { 7. Penilaian dan evaluasi }\end{array}$ \\
\hline
\end{tabular}

Sumber: Data primer diolah, 2018

\section{Motivasi Belajar}

Kata "motif" diartikan daya upaya yang mendorong seseorang untuk melakukan sesuatu. Motif juga sebagai daya penggerak dari luar dan di dalam subjek untuk melakukan aktivitas-aktivitas tertentu demi mencapai suatu tujuan. Berawal dari kata "motif", maka motivasi dapat diartikan sebagai daya penggerak dari luar dan dalam diri individu yang telah menjadi aktif. Motif menjadi aktif pada saat-saat tertentu, terutama bila kebutuhan untuk mencapai tujuan sangat dirasakan/mendesak (Sardiman, 2012). Dalam motivasi terkandung adanya keinginan yang mengaktifkan, menggerakkan, menyalurkan dan mengarahkan sikap dan perilaku individu belajar (Koeswara, 1989 dalam Dimyati dan Mudjiono 2009:80).

Ada dua macam sudut pandang motivasi belajar, yakni motivasi yang berasal dari dalam pribadi seseorang yang biasa disebut "motivasi intrinsik" dan motivasi yang berasal dari luar diri seseorang yang biasa disebut "motivasi ekstrinsik. Menurut A.M. Sardiman (2005:90) motivasi ekstrinsik adalah motifmotif yang aktif dan berfungsinya karena adanya perangsang dari luar. Adanya 
berbagai jenis motivasi di atas, memberikan suatu gambaran tentang motif-motif yang ada pada setiap individu. Adapun bentuk motivasi yang sering dilakukan disekolah adalah memberi angka, hadiah, pujian, gerakan tubuh, memberi tugas, memberi ulangan, mengetahui hasil, dan hukuman.

\section{Indikator Motivasi Belajar}

Penelitian ini, mengemukakan teori mengenai motivasi mahasiswa, di bawah ini dicantumkan indikator motivasi belajar mahasiswa yang akan diteliti. Tabel 2 Indikator motivasi belajar mahasiswa, sebagai berikut.

Tabel 2 Indikator Motivasi Belajar Mahasiswa

\begin{tabular}{|c|c|c|}
\hline Variabel & Sub Variabel & Indikator \\
\hline \multirow[t]{8}{*}{ Motivasi Siswa } & Intrinsik: & 1. Keinginan kuliah \\
\hline & $\begin{array}{l}\text { (Hal dan keadaan yang berasal dari } \\
\text { dalam diri mahasiswa sehingga }\end{array}$ & $\begin{array}{l}\text { 2. Senang mengikuti } \\
\text { perkuliahan }\end{array}$ \\
\hline & mendorong tindakan belajar) & $\begin{array}{l}\text { 3. Selalu menyelesaikan } \\
\text { tugas }\end{array}$ \\
\hline & & 4. Mengembangkan bakat \\
\hline & & $\begin{array}{l}\text { 5. Meningkatkan } \\
\text { pengetahuan }\end{array}$ \\
\hline & $\begin{array}{l}\text { Ekstrinsik: } \\
\text { (Hal dan keadaan yang berasal dari }\end{array}$ & $\begin{array}{l}\text { 1. Ingin mendapatkan } \\
\text { perhatian }\end{array}$ \\
\hline & luar dirimahasiswa, yang & 2. Ingin mendapatkan pujian \\
\hline & mendorongnya untuk belajar) & $\begin{array}{l}\text { 3. Ingin mendapatkan } \\
\text { penghargaan/hadiah dari } \\
\text { dosen atau kampus }\end{array}$ \\
\hline
\end{tabular}

Sumber: Data primer diolah, 2018

\section{Metode Penelitian}

Metode penelitian menggunakan pendekatan kuantitatif. Populasinya adalah mahasiswa Prodi Pendidikan IPS berjumlah 150 orang, terdiri dari angkatan 2015, 2016, dan 2017. Subjek penelitian berjumlah 150 mahasiswa pendidikan IPS dengan pengambilan sampel penuh. Satu variabel bebas yakni kompetensi pedagogik dan satu variabel terikat motivasi belajar. Data penelitian berupa primer dan sekunder. Data primer berupa observasi dan angket, adapun data sekunder berupa studi dokumen dan pustaka. Instrumen penelitian menggunakan angket tanggapan mahasiswa Pendidikan IPS. Analisis data menggunakan presentase dan perhitungan analisis regresi linier sederhana. Pengambilan keputusan dan makna hasil persentase menggunakan ketetapan, sebagai berikut pada tabel 3, sebagai berikut. 
Tabel 3. Kriteria Validitas Analisis Persentase

\begin{tabular}{cc}
\hline Tingkat Pencapaian & Kualifikasi \\
\hline $76-100 \%$ & Baik \\
$51-75 \%$ & Cukup \\
$26-50 \%$ & Kurang Baik \\
$0-26 \%$ & Tidak Baik \\
\hline
\end{tabular}

Sumber: Arikunto, 2009

\section{Hasil}

\section{Kompetensi Pedagogik}

Kompetensi pedagogik menggambarkan kemampuan dosen mengelola pembelajaran. Penelitian ini menggunakan 20 item pernyataan untuk mengukur variabel kompetensi pedagogik. Hasil angket ditabulasi untuk mengubah data dan instrumen pengumpul data (angket) menjadi tabel-tabel angka. Skala yang digunakan untuk menganalisis data yakni skala Likert dengan klasifikasi penilaian skor: 4) sangat setuju; 3) setuju; 2) tidak setuju; 1) sangat tidak setuju. Setiap skor yang didapatkan melalui angket, dilakukan penghitungan. Setiap item diberi skor tertinggi 4 dan terendah 1. Dengan demikian, jumlah skor kriterium tertinggi (skor tertinggi $\mathrm{x}$ item pertanyaan $\mathrm{x}$ jumlah responden), yaitu 4 × $20 \times 150=12000$. Jumlah skor kriterium terendah (skor terendah $\mathrm{x}$ item pertanyaan $\mathrm{x}$ jumlah responden), yaitu $1 \times 20 \times 150=3000$. Hasil perhitungan angket yang dibagikan kepada siswa, kemudian ditabulasikan ke dalam klasifikasi jawaban pada Tabel 4 sebagai berikut.

Tabel 4 Hasil Analisis Angket Kompetensi Pedagogik

\begin{tabular}{lcr}
\hline Kategori Jawaban & $\begin{array}{c}\text { Skor/item angket dikalikan dengan } \\
\text { jumlah jawaban }\end{array}$ & Jumlah \\
\hline Sangat Setuju & $4 \times 1058$ & 4232 \\
Setuju & $3 \times 1782$ & 5346 \\
Tidak Setuju & $2 \times 154$ & 308 \\
Sangat Tidak & $1 \times \quad 6$ & 6 \\
Setuju & & \\
\hline
\end{tabular}

Sumber: Data primer diolah, 2018

Berdasarkan Tabel 4 jumlah skor yang diperoleh dari hasil angket mahasiswa adalah 9892. Skor yang didapat $(9892 / 12000 \times 100 \%)=82,4 \%$ dari yang diharapkan 100\%. Hasil ini dikonversikan ke dalam Tabel 3 untuk klasifikasi tingkat kompetensi pedagogik dosen Pendidikan IPS termasuk kategori Baik. 


\section{Motivasi Belajar}

Kompetensi pedagogik menggambarkan kemampuan dosen mengelola pembelajaran. Penelitian ini menggunakan 20 item pernyataan untuk mengukur variabel kompetensi pedagogik. Hasil angket akanditabulasi menjadi tabel-tabel angka. Skala yang digunakan untuk menganalisis data yakni Skala Likert dengan klasifikasi penilaian skor: 4) sangat setuju; 3) setuju; 2) tidak setuju; 1) sangat tidak setuju. Setiap skor yang didapatkan melalui angket, dilakukan penghitungan. Setiap item diberi skor tertinggi 4 dan terendah 1. Dengan demikian, jumlah skor kriterium tertinggi (skor tertinggi $\mathrm{x}$ item pertanyaan $\mathrm{x}$ jumlah responden), yaitu 4 x 14 × $150=8400.4 \times 6 \times 150=3600$. Jumlah skor kriterium terendah (skor terendah $\mathrm{x}$ item pertanyaan $\mathrm{x}$ jumlah responden), yaitu 1 x 20 x $150=3000$. Hasil perhitungan angket yang dibagikan kepada siswa ditabulasikan ke dalam klasifikasi jawaban pada Tabel 5 sebagai berikut.

Tabel 5 Hasil Analisis Angket Motivasi Belajar Mahasiswa

\begin{tabular}{lcr}
\hline $\begin{array}{c}\text { Kategori } \\
\text { Jawaban }\end{array}$ & $\begin{array}{c}\text { Skor/item angket dikalikan dengan jumlah } \\
\text { jawaban }\end{array}$ & Jumlah \\
\hline Sangat Setuju & $4 \times 801$ & 3204 \\
Setuju & $3 \times 1030$ & 3090 \\
Tidak Setuju & $2 \times 228$ & 456 \\
Sangat Tidak & $1 \times 41$ & 41 \\
Setuju & & 6791 \\
\hline
\end{tabular}

Sumber: Data primer diolah, 2018

Hasil perhitungan angket yang dibagikan kepada mahasiswa ditabulasikan ke dalam klasifikasi jawaban pada Tabel 6 sebagai berikut.

Tabel 6 Hasil Analisis Angket Motivasi Belajar Mahasiswa

\begin{tabular}{|c|c|c|c|}
\hline $\begin{array}{l}\text { Kategori } \\
\text { Jawaban }\end{array}$ & $\begin{array}{l}\text { Skor/item angket } \\
\text { jawaban }\end{array}$ & dikalikan dengan jumlah & Jumlah \\
\hline Sangat Setuju & & $1 \times 172$ & 172 \\
\hline Setuju & & $2 \times 322$ & 644 \\
\hline Tidak Setuju & & $3 \times 296$ & 888 \\
\hline Sangat Tidak & & $4 \times 110$ & 440 \\
\hline
\end{tabular}

Sumber: Data primer diolah, 2018

Berdasarkan Tabel 5 dan 6, jumlah skor yang diperoleh dari hasil angket mahasiswa adalah 8935 . Skor yang didapat $(8935 / 12000 \times 100 \%)=74,5 \%$ dari yang diharapkan 100\%. Hasil ini dikonversikan ke dalam Tabel 3 untuk 
klasifikasi tingkat motivasi belajar mahasiswa Pendidikan IPS termasuk kategori cukup.

\section{Analisis Regresi Linear Sederhana}

Penghitungannya menggunakan program komputasi SPSS 16 for windows. Persamaan regresi ditentukan dengan menggunakan Tabel 7 output SPSS dengan judul Coefficients dengan melihat pada kolom Unstandardized Coefficients.

\section{Tabel 7 Analisis Regresi Linear Sederhana} Coefficients $^{\mathrm{a}}$

\begin{tabular}{|c|c|c|c|c|c|c|}
\hline \multirow{2}{*}{\multicolumn{2}{|c|}{ Model }} & \multicolumn{2}{|c|}{$\begin{array}{l}\text { Unstandardized } \\
\text { Coefficients }\end{array}$} & \multirow{2}{*}{$\begin{array}{c}\begin{array}{c}\text { Standardized } \\
\text { Coefficients }\end{array} \\
\text { Beta }\end{array}$} & \multirow[b]{2}{*}{$\mathrm{t}$} & \multirow[b]{2}{*}{ Sig. } \\
\hline & & B & Std. Error & & & \\
\hline \multirow[t]{2}{*}{1} & (Constant) & 33.276 & 4.621 & & 7.202 & .000 \\
\hline & Kompetensi Pedagogik & .399 & .070 & .425 & 5.712 & .000 \\
\hline
\end{tabular}

a. Dependent Variable: Motivasi Belajar

Sumber: Data primer diolah, 2018

Berdasarkan Tabel 7 menunjukkan nilai $\mathrm{a}=$ angka konstanta dari unstandardized coefficients sebesar 33,276. Nilai konstanta menunjukkan bahwa jika variabel bebas (kompetensi pedagogik dosen) diasumsikan tidak ada, maka nilai variabel terikat (motivasi belajar mahasiswa) sebesar 33,276. Dengan demikian, motivasi belajar mahasiswa Pendidikan IPS sebelum atau tanpa adanya kompetensi pedagogik dosen sebesar 33,276. Nilai $b=$ angka koefisien dari unstandardized coefficients sebesar 0,399. Nilai koefisien regresi tersebut memiliki arti, setiap kenaikan kualitas kompetensi pedagogik dosen sebesar 1 poin, maka motivasi belajar mahasiswa akan meningkat sebesar 0,399. Dengan demikian, nilai koefisien regresi 0,399 (positif) menunjukkan kompetensi pedagogik dosen berpengaruh positif terhadap motivasi belajar mahasiswa. Berdasarkan hasil analisis tersebut, maka persamaan regresinya $\mathrm{Y}=33,276+0,399$.

\section{Analisis Determinasi}

Perhitungan nilai determinasi untuk mengetahui besaran kontribusi pengaruh variabel bebas $(\mathrm{X})$ terhadap variabel terikat $(\mathrm{Y})$. Penentuan nilainya menggunakan hasil Tabel 8 output SPSS dengan judul tabel Model Summary. 
Tabel 8 Hasil Analisis Determinasi

Model Summary ${ }^{\text {b }}$

\begin{tabular}{|l|r|r|r|r|}
\hline Model & \multicolumn{1}{|c|}{$\mathrm{R}$} & R Square & $\begin{array}{c}\text { Adjusted R } \\
\text { Square }\end{array}$ & $\begin{array}{c}\text { Std. Error of } \\
\text { the Estimate }\end{array}$ \\
\hline 1 & $.425^{\mathrm{a}}$ & .181 & .175 & 4.953 \\
\hline
\end{tabular}

a. Predictors: (Constant), Kompetensi Pedagogik

b. Dependent Variable: Motivasi Belajar

Sumber: Data primer diolah, 2018

Berdasarkan Tabel 8 menunjukkan nilai determinasi (R2) sebesar 0,181. Nilai determinasi (R2) selanjutnya dihitung dengan persentase, maka KD $=\mathrm{R} 2 \mathrm{x}$ $100 \% \Leftrightarrow 0,181 \times 100 \%=18,1 \%$. Dengan demikian, kompetensi pedagogik dosen mempengaruhi motivasi belajar mahasiswa Pendidikan IPS sebesar 18,1\% dan sisanya $(100 \%-18,1 \%=81,9 \%)$ dipengaruhi oleh faktor lain di luar kompetensi pedagogik dosen.

\section{Uji Hipotesis}

Pengujian hipotesis untuk memastikan apakah koefisien regresi tersebut signifikan atau tidak (Apakah Ho ditolak dan Ha diterima atau Ho diterima dan Ha ditolak). Uji hipotesis menggunakan uji t (membandingkan nilai thitung dengan $\left.t_{\text {tabel }}\right)$. Dengan ketentuan Ho ditolak jika $t_{\text {hitung }}>t_{\text {tabel }}$ dan Ha diterima atau sebaliknya. Hasil uji t diperoleh dari output SPSS dari hasil regresi linear sederhana pada tabel 5 berjudul Coefficients dengan melihat kolom t. Berdasarkan hasil tersebut nilai $t_{\text {hitung }}$ sebesar 5,712 dengan nilai signifikansi sebesar 0,000. Nilai $t_{\text {tabel }}$ untuk $\mathrm{n}=150$ dan nilai signifikansi $(0,05)$ sebesar 1,976 . Nilai $t_{\text {hitung }}$ $(5,712)>t_{\text {tabel }}(1,976)$, maka dapat dinyatakan bahwa uji hipotesisnya Ho ditolak dan Ha diterima. Dengan demikian, kompetensi pedagogik dosen berpengaruh secara signifikan terhadap motivasi belajar mahasiswa.

\section{E. Pembahasan}

\section{Kompetensi Pedagogik Dosen}

Bagi seorang dosen penguasaan kompetensi pedagogik dengan baik tentu akan mempengaruhi hasil pembelajaran yang optimal. Kompetensi pedagogik menggambarkan bagaimana seorang dosen melaksanakan pembelajaran dengan baik, menguasai karakteristik mahasiswa, menguasai teori belajar dan prinsipprinsip pembelajaran, pengembangan kurikulum, pengembangan potensi 
mahasiswa, komunikasi dengan baik kepada mahasiswa serta mampu menggunakan hasil evaluasi untuk meningkatkan kualitas pembelajaran. Dengan demikian, semakin baik kompetensi pedagogik seorang dosen akan semakin baik juga kualitas pembelajaran, tentunya juga akan meningkatkan kinerja dosen. Penelitian yang dilakukan terhadap kompetensi pedagogik dosen Pendidikan IPS sudah baik. Tingkat kompetensi pedagogik dosen berdasarkan hasil angket mahasiswa sebesar 82,4\%. Dengan demikian, berdasarkan hasil persentase kompetensi pedagogik dosen Pendidikan IPS berada pada kategori baik.

\section{Motivasi Belajar Mahasiswa}

Seorang mahasiswa yang memiliki motivasi tinggi mencari ilmu, akan mengikuti pembelajaran dengan baik. Motivasi sebagai daya penggerak individu untuk menimbulkan kelangsungan pembelajaran ke arah yang lebih baik. Dengan demikian, mahasiswa yang memiliki motivasi akan memiliki tingkat belajar yang tinggi pula, sehingga mempercepat hasil yang ingin dicapai. Penelitian yang dilakukan terhadap motivasi belajar mahasiswa Pendidikan IPS sudah baik. Tingkat motivasi belajar berdasarkan hasil angket mahasiswa sebesar 74,5\%. Dengan demikian, berdasarkan hasil presentase motivasi belajar mahasiswa Pendidikan IPS berada pada kategori cukup.

\section{Pengaruh Kompetensi Pedagogik Dosen Terhadap Motivasi Belajar}

Berdasarkan hasil analisis data terbukti bahwa, antara variabel $\mathrm{X}$ (kompetensi pedagogik) dan variabel Y (motivasi belajar) nilai koefisien regresi bernilai 0,399 (positif) menunjukkan kompetensi pedagogik dosen berpengaruh positif terhadap motivasi belajar mahasiswa. Pengaruh positif mengindikasikan bahwa semakin tinggi tingkat kompetensi pedagogik dosen Pendidikan IPS semakin meningkat pula tingkat motivasi belajar mahasiswa.

Selanjutnya untuk mengetahui apakah hubungan itu signifikan atau tidak maka " $t$ " hasil perhitungan dibandingkan dengan "t" tabel. Sampel penelitian berjumlah 150 mahasiswa. Berdasarkan hasil perhitungan, nilai $t_{\text {hitung }}$ sebesar 5,712 dengan nilai signifikansi 0,000 . Nilai $t_{\text {tabel }}$ untuk $n=150$ dan nilai signifikansi $(0,05)$ sebesar 1,976 . Nilai $t_{\text {hitung }}(5,712)>t_{\text {tabel }}(1,976)$, maka dapat dinyatakan bahwa uji hipotesisnya Ho ditolak dan Ha diterima. Dengan demikian, 
kompetensi pedagogik dosen berpengaruh secara signifikan terhadap motivasi belajar mahasiswa.

\section{F. Kesimpulan}

Kesimpulan dalam penelitian ini sebagai berikut:

1. Tingkat kompetensi pedagogik dosen berdasarkan hasil angket mahasiswa sebesar $82,4 \%$. Hasil persentase tersebut menunjukkan bahwa kompetensi pedagogik dosen Pendidikan IPS berada pada kategori baik.

2. Tingkat motivasi belajar berdasarkan hasil angket mahasiswa sebesar $74,5 \%$. Hasil persentase tersebut menunjukkan bahwa motivasi belajar mahasiswa Pendidikan IPS berada pada kategori cukup.

3. Berdasarkan hasil perhitungan, nilai koefisien regresi bernilai 0,399 (positif) menunjukkan kompetensi pedagogik dosen berpengaruh positif terhadap motivasi belajar mahasiswa. Besarnya kontribusi kompetensi pedagogik dosen mempengaruhi motivasi belajar mahasiswa Pendidikan IPS sebesar 18,1\% dan sisanya $(100 \%-18,1 \%=81,9 \%)$ dari motivasi belajar mahasiswa dipengaruhi oleh faktor lain di luar kompetensi pedagogik dosen.

4. Berdasarkan hasil perhitungan, nilai $t_{\text {hitung }}$ sebesar 5,712 dengan nilai signifikansi 0,000 . Nilai $t_{\text {tabel }}$ untuk $n=150$ dan nilai signifikansi $(0,05)$ sebesar 1,976. Nilai $t_{\text {hitung }}(5,712)>t_{\text {tabel }}(1,976)$, maka dapat dinyatakan bahwa uji hipotesisnya Ho ditolak dan Ha diterima. Dengan demikian, kompetensi pedagogik dosen berpengaruh secara signifikan terhadap motivasi belajar mahasiswa.

Berdasarkan simpulan yang telah dikemukakan dalam penelitian, saran yang dapat diajukan, (1) melihat adanya tingkat pengaruh yang positif antara kompetensi pedagogik dosen terhadap motivasi belajar mahasiswa Pendidikan IPS, sebaiknya dosen terus meningkatkan kompetensi pedagogik tersebut agar lebih memotivasi mahasiswa menempuh perkuliahan, (2) selain kompetensi pedagogik yang lebih ditingkatkan, kompetensi professional, kepribadian, dan sosial juga perlu ditingkatkan. Berdasarkan hasil penelitian pengaruh kompetensi pedagogik dosen masih tergolong kecil untuk memotivasi belajar mahasiswa, kemungkinan besar 3 (tiga) kompetensi lainnya yang mempengaruhi motivasi 
belajar mahasiswa. dan (3) penelitian selanjutnya agar menambahkan variabel 3 (tiga) kompetensi lainnya dalam penelitian karena variabel kompetensi pedagogik sangat kecil pengaruhnya terhadap motivasi belajar mahasiswa Pendidikan IPS.

\section{Daftar Pustaka}

Arikunto, Suharsimi. 2009. Prosedur Penelitian Suatu Pendekatan Praktik. Jakarta. PT. Rineka Cipta.

Dimyati dan Mudjiono. 2009. Belajar dan Pembelajaran. Jakarta. PT. Rineka Cipta

Makmun, A. S. 2007. Psikologi Kependidikan Perangkat Sistem Pengajaran Modul. Bandung. PT. Remaja Rosdakarya.

Mulyasa. 2007. Standar Kompetensi dan Sertifikasi Guru. Bandung. Remaja Rosdakarya

Mustamin, Fattah. 2013. Kompetensi Pedagogik Guru Bahasa Arab Madrasah Aliyah Se Kota Samarinda. Jurnal Fenomena, Volume V, No. 1.

Peraturan Pemerintah Republik Indonesia Nomor 19 Tahun 2005 Tentang Standar Nasional Pendidikan.

Sardiman A.M. 2005. Interaksi dan Motivasi Belajar Mengajar. Jakarta. PT. Raja Grafindo Persada

Undang-Undang Republik Indonesia Nomor 14 Tahun 2005, tentang Guru dan Dosen. 